\title{
A Multivariate Analysis of the General Skills Developed in Accounting Higher Education
}

\author{
ALEXANDRA DOMINGOS \\ Lisbon Accounting and Business School (ISCAL) \\ Lisbon Polytechnic Institute (IPL), Lisbon, Portugal. \\ Email: amrodrigues@iscal.ipl.pt \\ Tel: +351217984500 \\ Corresponding author \\ MANUELA SARMENTO \\ Lusíada University of Lisbon, Lisbon, Portugal \\ Email: manuela.sarmento2@gmail.com \\ Tel: +351213611500 \\ MANUELA DUARTE \\ Lisbon Accounting and Business School (ISCAL) \\ Lisbon Polytechnic Institute (IPL), Lisbon, Portugal. \\ Email: manueladuarte@netcabo.pt \\ Tel: +351217984500
}

\begin{abstract}
The literature shows important and crucial changes in higher education, motivated by the rapid advance of technology and a constantly changing organizational environment. This study aims to analyze final-year students' and accounting lecturers' perceptions about the development of general skills in first-cycle courses in order to improve skills taught in accounting courses to facilitate students' entry into the labour market. A questionnaire-based survey was applied to 345 final-year students and 155 accounting lecturers at Portuguese higher education institutions. The answers obtained were statistically analyzed by factor analysis by the principal component method. The results of two individual factor analyses indicated differences in the factors that represent the skills perceived as developed throughout the academic course: students indicated teamwork and pressure tolerance as the factors that explain the most developed skills, while accounting lecturers considered problem-solving as the most developed dimension. These results are very important for accounting educators in Portugal to complement their teaching, along with other learning strategies present in the literature review.
\end{abstract}

Keywords: Accounting Education, Competence Development, Student Perception, Accounting Lecturers' Perception.

\section{Introduction}

Globalization, capital market expansion and recent changes in the economic environment have created new needs that imply a transformation of the accounting approach and specifically a different perspective on how to prepare future accounting professionals to deal with this new reality. The rising expectations of employers, clients and various stakeholders have created a demand for accounting professionals that go beyond the traditional theoretical knowledge and higher education and have a wide range of skills covering other areas of expertise. 
As knowledge workers, accountants can help their organizations excel by creating added value. Their knowledge, problem-solving skills, initiative and creativity, combined with specific knowledge, were favored by employers (Kavanagh \& Drennan, 2008). This situation therefore represents a change in profile, as it is necessary to change the paradigm from a highly technical professional to someone who can use various skills.

The development of competent professionals is one of the aims of accounting education. According to the International Federation of Accountants (IFAC, 2011), through the International Accounting Education Standards Board (IAESB), 'competence' is defined as the ability to perform a given role complying with a certain reference standard. To demonstrate their competence, accountants must have the required professional knowledge and qualifications, values and an ethical approach (IFAC, 2011).

Accounting teaching techniques have been primarily traditional teacher-centered methods (lectures or conferences) rather than modern student-oriented applications and techniques. The implementation of the Bologna Process created a new environment that fostered the debate on teaching and learning as privileged individual learning and teamwork, based on creativity and autonomy, within a framework that aims to better prepare students for the labour market by contrary to the old approach to theoretical teaching. Thus, general skills seem to have gained momentum as they are considered essential and closely linked to professional success (Jackling \& De Lange, 2009; Paisey \& Paisey, 2010; Van der Klink, Boon, \& Schlusmans, 2007).

According to some researchers, student performance in accounting courses over the years has been consistently low (Bui \& Porter, 2010; Jackling \& De Lange, 2009; Kavanagh \& Drennan, 2008). Arquero and Fernández-Polvillo (2019) point out that the divergence between real demands and students' perceptions may stem from a misconception of what an accountant's tasks are and the skills needed for a 21 st century professional. Note that while the vision is not stereotyped, students do not seem clear that accounting tasks require increasingly integrated multidisciplinary working groups and efficient communication with professionals with other profiles, which requires them to go beyond mere number reports to be able to effectively explain the implications of these numbers (Arquero, Donoso, Hassall \& Joyce, 2001; Arquero \& Fernández-Polvillo, 2019).

The teaching-learning process has been the subject of discussion and research aimed at contributing to its development and effectiveness. Among the agents that are part of the teaching-learning process, the student is considered the main target, since fulfilment of the objective of the process only materializes only with the effective learning by the student. Empirical experiments in accounting show that students are more interested in subjects in which they identify practical applications of content rather than subjects where the connection between theory and practice is not explicit (Almeida et al., 2015). By implementing a studentcentered approach in the classroom, the hope is to have a self-confident, critical-thinking student who fully understands accounting terminology and fundamentals.

Rapid technological developments have provided tools and services for millennial students who were not in the imagination of previous generations. Mobile devices and the internet are two main features of this generation's daily life. In this sense, the introduction of new forms of accounting education, combining attitudes and didactic resources that facilitate the learning process, seems to be on the agenda in terms of effective teaching-learning strategies. Higher Education Institutions (HEI) concerned with training competent and competitive professionals should consider the environment in which a future professional will carry out their activities and should be aware of the need for education adapted to workplace requirements.

The purpose of this study is to analyze final-year students' and accounting lecturers' perceptions about the development of general skills in first-cycle courses in order to improve the skills taught in accounting courses to facilitate students' entry into the labour market. The complexity of the context and the learning 
strategies to improve student performance are highlighted. The results demonstrate that HEI skills development remains a problem. We highlight the usefulness of the study for the courses analyzed, in order to encourage improvements that contribute to the alignment of study plans with professional expectations. This paper is divided into three sections. The literature review focuses on the importance of higher education skills and the motivation and learning strategies in accounting. Subsequently, research questions are formulated, followed by an analysis of the data obtained in the survey's responses. The last section discusses the results.

\section{The importance of Higher Education Skills}

McClelland is recognized in the literature as the engine of the competence debate, relating individual characteristics to work performance, following White's (1959) approach to conceptualized competence as the individual's ability to effectively interact with the environment, depending on his or her motivation to achieve this goal.

The literature review finds that there is no universally accepted concept of competence, just as the view on the subject is not uniform. There is a general lack of consensus among authors about the meaning of competence. It also varies depending on the context or field in which the term is used. However, there is a consensus that competence represents a combination of knowledge, skill, aptitude and other individual characteristics that can be reliably measured and show their differentiation in performance (Rouco \& Sarmento, 2012).

Concerns expressed in the literature on the definition of competence also reveal the desire to discover what underlies each element of competence by trying to identify and understand the different components or dimensions. Traditionally, according to Rouco and Sarmento (2012), the acronym KSAO (knowledge, skill, ability and others) was attributed to Harvey (1991); it is used to describe and organize individual and essential characteristics to perform the job successfully.

Originally, the acronym appeared as KSA (knowledge, skill, ability), which represented knowledge, ability and attitudes. Over the years, and depending on the sources, the acronym has evolved and acquired other meanings:

- $\quad$ Knowledge $(\mathrm{K})$ and skill $(\mathrm{S})$ have always existed as knowledge and ability, respectively.

- Ability (A) sometimes represents aptitude, which is sometimes synonymous with attributes or attitudes;

- Other characteristics $(\mathrm{O})$ often arise when A represents aptitude.

According to Harvey (1991), the various competence components have the following meanings:

- Knowledge is indispensable information required to perform tasks associated with a particular function. It is acquired through formal education, professional training or professional experience.

- Skill (ability) comprises the resourcefulness of the use of instruments and equipment in each function. This ability can be acquired in an educational setting or learned informally.

- Ability results from the interconnectedness of concepts such as intelligence, spatial orientation and reaction time. Skills are often measured through tests that provide estimates of a person's specific ability to perform a task.

- 'Other' are the additional characteristics needed to perform well at work, such as attitude, personality, initiative, creativity, or improvisation.

The Bologna Process aimed to develop students' ability to apply knowledge gained in different contexts and situations and to shift the traditional focus on theoretical knowledge to a skill-based approach. This skill-based training process required a cultural shift in HEI, lecturers, and students. In this context, and together with other technical aspects, HEI must develop scientific, systemic and relational skills in order to train dynamic and adaptable professionals able to keep up with rapid changes in the labour market. 
Therefore, the role played by HEI in the formation of students is fundamental and seeks to promote good reputation and recognition in the labour market.

Kavanagh and Drennan (2008) state that: "accounting educators worldwide are being urged to alter curriculum to produce accounting graduates with a broader set of skills and attributes encompassing more than purely technical accounting expertise" (p. 280). The concept of general skills differs from the concept of specific skills (associated with a particular function or occupation) due to two traits: transversely - the lack of specifics and adaptation to contexts - and transferability, acquired in a given context but usable in different contexts (Ceitil, 2016). Therefore, there is increasing pressure on accounting educators to design and implement educational programs that can contribute to the development of relevant skills (Arquero, Fernández-Polvillo, Hassall, \& Joyce, 2017).

Currently, accounting graduates are expected to have a broad set of technical and generic skills to meet workplace requirements. There is a consensus among employers and academics that in many cases the necessary personal skills and qualities are not being displayed (Jackling \& De Lange, 2009). Another concern is the ability of students to adapt and develop the necessary skills, given current pedagogy. The traditional approach, which tends to focus on intellectual skills framed by the necessary technical knowledge, may need to be broadened to incorporate a specific focus on the application of knowledge, thereby enabling the development of problem-solving skills.

Pincus, Stout, Sorensen, Stocks and Lawson (2017) point out that there is convincing evidence of strong forces for change in higher education. The current environment is shaped and challenged by two main forces: the rapid advancement of technology and a dramatically challenging financial model. They add that, as members of the academy, business and accounting educators are not immune to these forces at the macro level. Understanding the forces for change is critical to motivating strategic and operational change at the institutional, programmatic, and personal levels.

Some academic research into the changes needed to meet employers' needs has identified several key areas: (1) intellectual skills (problem-solving and decision-making); (2) technical and functional skills (mainly technical content); (3) personal skills (including the ability to adapt to change and throughout life); (4) interpersonal and communication skills (working with others, team integration and effective communication); and (5) organizational and business management skills. These skills are similar to those stipulated by IES 3 from IAESB (2015) as necessary requirements in a professional accounting education program.

IES 3 states that general education requirements vary widely from one program to another and from country to country; it further establishes that general education can encourage lifelong learning and provide its foundations and can be acquired in different ways and in different settings at any stage of the educational program.

In their study, Jackling and De Lange (2009) asked accounting graduates to name the most important skills for progression. Communication was ranked first, followed by problem-solving. This does not only apply to large companies; employers of midsize and small businesses emphasized the importance of communication skills (Bui \& Porter, 2010).The above recent results are consistent with previous literature (Arquero et al., 2001, 2017) in a European context and with Jackling and De Lange (2009) and Kavanagh and Drennan (2008) from an Australian perspective.

Arquero et al. (2017) argues that there is a clear demand for accounting educators who focus on developing professional skills in training future accountants. Previous attempts have been relatively unsuccessful in remedying this perceived need. The question that needs to be addressed is what may be hindering the success of attempts to improve communication skills. In this context, the results obtained by Arquero et al. (2017) conclude that it is possible that some student's characteristics, such as apprehension of 
communication, tolerance for ambiguity or learning styles, may act as constraints on skills development and pedagogical change. The authors emphasize that an additional concern is the ability of students to adapt and develop the necessary skills, given the current pedagogy. A different approach between academics and students may be necessary as the traditional approach tends to focus on the intellectual skills framed by the necessary technical knowledge, and this needs to branch out to incorporate a specific focus on the application of knowledge and thus enable the development of knowledge about problem-solving skills.

\section{Motivation and Learning Strategies in Accounting}

There is much research analyzing motivation and learning strategies in students enrolled on different courses, following different teacher methodologies (Arquero et al., 2017; Chamizo-Gonzalez, CanoMontero, Urquía-Grande, \& Muñoz-Colomina, 2015; Rivero-Menéndez, Urquía-Grande, López-Sánchez, \& Camacho-Miñano, 2018).

According to Glynn and Koballa (2006), motivation is an internal state that awakens, directs and sustains students' behavior. Motivation to learn refers to the way students think about themselves about learning activities and processes. Learning strategies are the activities that individuals use to assist them in acquisition, storage, and retrieving of information (Oxford \& Nyikos, 1989).

Harandi (2015) highlights motivation as a prerequisite for student involvement in any type of learning activity. Concern about the role of student motivation in academic performance has been widespread. A very common belief is that a lack of motivation usually leads to poor results.

Lynch (2008) stats that motivational beliefs and learning strategies have a significant effect on student learning. According to the author, there is a well-documented relationship between motivation and use of learning strategies, and these are indispensable tools for autonomous and self-regulated learning.

Regarding motivation, Arquero and Fernández-Polvillo (2019) conclude that students choose a career in accounting because of their job prospects. The student's potential effort in relation to certain content will therefore be closely linked to the perception of utility in the sense of later practical application. The authors argue that the link between content and practical utility should be reinforced, especially in theoretical content and some non-technical skills (communication, complex and unstructured problem-solving, application of professional judgment) to which students attach little importance. They do not correspond to your view of typical accounting tasks but are essential both from a professional and higher education perspective.

Today, technological forces are significantly changing many professions, including accounting. Digital technologies offer the opportunity to prepare students for 21 st century careers and to create new financial models for higher education. Thus, HEIs are under pressure from stakeholders and institutional contexts to shift their pedagogy to a more active one in which student is more autonomous and involved in his or her own learning process. Arquero et al. (2017) state that certain personal characteristics of students may act as constraints to skills development and pedagogical change.

Jackling and De Lange (2009) find that employers require a wide range of general skills that accounting graduates admit is not adequately taught in their undergraduate degrees. From their own perspective, employers emphasize the importance of teamwork, leadership, verbal communication, and interpersonal skills.

Criticisms of teaching methodologies used in higher education are addressed in several areas, with criticism of foreground lectures due to their unilateral and tax characteristics. However, it appears that strategies are emerging to bridge this gap, such as business simulation practices. Applying the knowledge gained in other disciplines by creating a work-like environment, business simulation practices seek to develop the skills 
and abilities that determine the proper performance of the functions and tasks inherent in the underlying professional activity. According to some studies (Almeida et al., 2015; Burdon \& Munro, 2017; Pincus et al., 2017), business simulation practices actively contribute to the quality of student training, as well as to the adequacy of profiles that the labour market needs.

Almeida et al. (2015) point out the main advantages of business simulation practices: (1) allow a practical view of the profession; (2) allow an approximation of the ethical experience of the profession and business; (3) develop the ability to work under pressure; (4) develop teamwork; (5) develop critical analyzes of one's own work and that of others; (6) improve oral and written expression skills; (7) develop the leadership and teamwork values typical of a living business organization (difficult to learn during the individual study phase); and (8) promote awareness that the qualities and skills acquired during the course will create conditions for professional success.

Burdon and Munro (2017) used an intensive audit simulation and found that this type of practice improves learning and sustainable skills that can be transferred to future jobs. Although Pincus et al. (2017) consider progress in the use of technology in new ways for teaching and learning to be slow, they agree that the simulations offer a similarity between the learning situation and the future professional environment, supporting education and training.

As Arquero and Tejero (2011) note, students should have a higher level of independence and responsibility and get the most benefit from the sources and activities at their disposal. However, to make the best use of those resources, students must be able to be active participants, be independent learners, and collaborate with other students working in teams. Commitment to lifelong learning and problem-solving skills, the key skills emphasized in employability reports and specifically in financial statements, require students to be independent learners. Teamwork is another essential employability skill that requires current students (future professionals) to be collaborative learners.

On the other hand, Chamizo-Gonzalez et al. (2015) studied teaching methodologies combined with online tools with the implementation of different multimedia resources (data mining) to improve learning outcomes in accounting higher education in order to provide students with cognitive and transversal skills for incorporation successful in the labour market. The authors' research aimed to disclose whether accounting students who participate in teacher-proposed online activities achieve better learning outcomes and identify which virtual learning activities achieve better results.

Another learning strategy is studied by Rivero-Menéndez, Urquía-Grande, López-Sánchez and CamachoMiñano (2018), who analyze whether there are differences between students' motivation and learning strategies when studying accounting subjects in Spanish or English as a means of instruction. The authors highlight the factors that mainly influence the overall motivation of the students. They find that students who study English have more mature learning strategies and motivation than their Spanish counterparts. This is shown in their level of self-confidence, time management, and perseverance. The authors' findings serve as a guide for teachers to help students improve their study, perseverance, and reflection methodology. The latter should be encouraged by teachers, understanding that motivation is dynamic, not static, and learning strategies can be developed. By learning about student strategies (such as selfregulation and time management), instructors can tailor their teaching procedures to help students achieve deep learning.

\section{Purpose and Research Questions}

The aim of this study is to examine final-year students' and accounting lecturers' perceptions of first-cycle courses at Portuguese educational institutions (universities and polytechnics) in terms of the development of general skills acquired during the course they attended. This goal leads to the following research questions: 
RQ1: What are the general skills that final-year students enrolled in undergraduate accounting courses perceive as being developed in their degrees?

RQ2: What are the general skills that accounting lecturers perceive that final-year students develop during the undergraduate courses they teach?

\section{Research Methodology}

\section{Variables definition}

To answer the above questions, we use a quantitative approach. Based on the nature of this study, the data collection instrument used was the questionnaire, as it is the most appropriate for this context and with the most associated potential. This choice was based on the fact that questionnaire is a quantitative research tool that, according to Sarmento (2013), provides primary data, considering that this data is produced by the researcher and driven by a specific need for information.

In the first phase, a literature review was performed to identify the skills required from an accountant. This identification considered the skills indicated by national and international entities, as well as those that different authors present in the literature review consider more relevant. Our objective was to select relevant skills from a solid scientific basis reflected in questionnaire. Thus, the identification of the skills that would form the basis for the variables included three phases: a literature review of the concept of competence, analysis of the most cited skills and subsequent grouping of these skills. Throughout the grouping process, where the essence of a skill was contained in one mentioned earlier, we merged them. We also had to share some of the skills when they incorporated more than one idea. Forty-nine skills were identified.

This process allowed us to make the skills defined logical and clearly, avoiding repeated ideas and consequently preventing interpretation errors. This was the most difficult step in building the second part of the data collection instrument, as there was a need to prevent the inclusion of multiple issues (Hill \& Hill, 2012). Table 1 below presents the skills most frequently mentioned in the literature review and which should be developed in the educational context.

Table 1. Skills to be developed in accounting higher education

\begin{tabular}{|c|c|}
\hline SKILLS & SOURCE \\
\hline $\begin{array}{c}\text { Communication } \\
\text { (oral and written) }\end{array}$ & $\begin{array}{c}\text { Almeida (2004); Hassall et al. (2005); IAESB (2015); } \\
\text { Jackling and De Lange (2009); Kavanagh and } \\
\text { Drennan (2008) }\end{array}$ \\
\hline Teamwork & $\begin{array}{c}\text { Almeida (2004); Hassall et al. (2005); IAESB (2015); } \\
\text { Jackling and De Lange (2009); Kavanagh and } \\
\text { Drennan (2008); Pan and Perera (2012) }\end{array}$ \\
\hline Organization & Hassall et al. (2005) \\
\hline Identify problems & $\begin{array}{c}\text { Almeida (2004); Cory and Pruske (2012); IAESB } \\
\text { (2015); Kavanagh and Drennan (2008); Pan and } \\
\text { Perera (2012) }\end{array}$ \\
\hline Problem-solving & $\begin{array}{c}\text { Almeida (2004); Cory and Pruske (2012); IAESB } \\
\text { (2015); Kavanagh and Drennan (2008); Pan and Perera } \\
\text { (2012) }\end{array}$ \\
\hline Use information and communication \\
technologies & $\begin{array}{c}\text { Almeida (2004); Cory and Pruske (2012); IAESB } \\
\text { (2015); Jackling and De Lange (2009); Kavanagh and } \\
\text { Drennan (2008) }\end{array}$ \\
\hline Accounting ethics & $\begin{array}{c}\text { Almeida (2004); Cory and Pruske (2012 IAESB } \\
\text { (2015); Jackling and De Lange (2009); Kavanagh and }\end{array}$ \\
\hline
\end{tabular}




\begin{tabular}{|c|c|}
\hline & $\begin{array}{l}\text { Drennan (2008); Order of Certified Accountants } \\
\text { (OCC) }\end{array}$ \\
\hline Leadership & IAESB (2015); Kavanagh and Drennan (2008) \\
\hline Interpersonal relationships & $\begin{array}{c}\text { Jackling and De Lange (2009); Kavanagh and } \\
\text { Drennan (2008) }\end{array}$ \\
\hline Creativity & Kavanagh and Drennan (2008) \\
\hline Decision-making & IAESB (2015); Kavanagh and Drennan (2008) \\
\hline Critical analysis & Almeida (2004); IAESB (2015) \\
\hline Self-criticism & Almeida (2004); IAESB (2015) \\
\hline Work under pressure & Almeida (2004) \\
\hline General knowledge & Almeida (2004) \\
\hline Negotiability & IAESB (2015); Kavanagh and Drennan (2008) \\
\hline Lifelong learning & IAESB (2015); Kavanagh and Drennan (2008); OCC \\
\hline Open-mindedness toward new opportunities & IAESB (2015) \\
\hline Conflict management & Almeida (2004); IAESB (2015) \\
\hline Work autonomously & Kavanagh and Drennan (2008) \\
\hline Research & IAESB (2015); Kavanagh and Drennan (2008) \\
\hline Information analysis & Almeida (2004); IAESB (2015) \\
\hline $\begin{array}{l}\text { Integrate information, Professional judgment } \\
\text { Reasoning, Innovative thinking, Cooperation } \\
\text { Professional skepticism, People management } \\
\text { Ability to motivate others, Comply with } \\
\text { deadlines and regulations, Time management }\end{array}$ & IAESB (2015) \\
\hline Apply knowledge to practice & Almeida (2004) \\
\hline $\begin{array}{c}\text { Assess the need to resort to experts from } \\
\text { different areas }\end{array}$ & IAESB (2015); OCC \\
\hline Intercultural communication & Cory and Pruske (2012); IAESB (2015) \\
\hline Resource management & IAESB (2015); Kavanagh and Drennan (2008) \\
\hline Delegate tasks & Hassall et al. (2005); IAESB (2015) \\
\hline $\begin{array}{l}\text { Data-processing, Organize information, } \\
\text { Understanding of the contexts in which } \\
\text { accounting operates, Prepare financial } \\
\text { statements, Perform a financial analysis, } \\
\text { Budgeting capacity, Prepare a management } \\
\text { panel with useful information for decision- } \\
\text { making, Prepare reports on performance } \\
\text { deviations }\end{array}$ & Almeida (2004) \\
\hline Report information & Almeida (2004); IAESB (2015); OCC \\
\hline Understanding technical accounting language & $\begin{array}{l}\text { Almeida (2004); Jackling and De Lange (2009); } \\
\text { Kavanagh and Drennan (2008) }\end{array}$ \\
\hline $\begin{array}{c}\text { Plan tasks, Assess the quality of work } \\
\text { performed }\end{array}$ & $\mathrm{OCC}$ \\
\hline
\end{tabular}

These skills were submitted to a validation committee of fourteen accounting specialists to ensure that the skills and their interpretation met the objectives of the research work and to avoid ambiguity and bias in the questions (Sarmento, 2013). The validation committee was asked to decide whether these skills were essential for a professional accountant, based on two standard answers: 'yes' or 'no'. Positive responses included in the third quartile $(75 \%)$ were considered. Twenty-seven skills were confirmed in this validation process, as shown in Table 2 below. 
Table 1. Skills validation

\begin{tabular}{|ll|}
\hline & \\
\hline 1 & SKILLS \\
2 & Problem-solving \\
3 & Information analysis \\
4 & Use information and communication technologies \\
5 & Organize information \\
6 & Accounting ethics \\
7 & Understanding of the contexts in which accounting operates \\
8 & Communication (oral and written) \\
9 & Decision-making \\
10 & Apply knowledge to practice \\
11 & Report information \\
12 & Understanding technical accounting language \\
13 & Organization \\
14 & Perform a financial analysis \\
15 & Teamwork \\
16 & Critical analysis \\
17 & Self-criticism \\
18 & Lifelong learning \\
19 & Plan tasks \\
20 & Comply with deadlines and regulations \\
21 & Assess the quality of work performed \\
22 & Work under pressure \\
23 & Interpersonal relationships \\
24 & Integrate information \\
25 & Time management \\
26 & Reasoning \\
27 & Prepare a management panel with useful information for decision-making \\
\hline
\end{tabular}

\section{Questionnaire and Data Collection}

After skills validation, two questionnaires were prepared. The authors first produced a draft questionnaire. This was reviewed and validated by a four expert validation committee. Finally, it was pilot tested with a group of final-year students and accounting lecturers.

The questionnaire used in this research included two sections. The first section contained questions on participants' demographic variables. The second section contained the twenty-seven skills, divided into sixteen general skills and eleven specific skills, with their respective descriptions. The descriptions obtained for each competency resulted from the critical analysis of reference material and the different reviewed articles. The questionnaire used a seven-point Likert scale with the following options: (1) strongly disagree; (2) disagree mainly; (3) partly disagree; (4) does not agree or disagree; (5) agree to some extent; (6) agree mainly; (7) totally agree.

To improve reliability, the questionnaire was revised and validated through in-depth personal interviews with four accounting specialists. Note that the analysis and contribution of each committee member was obtained directly and individually to avoid the contamination of opinions. The objectives of this validation were to test the readability and appropriateness of multi-level research (such as the appropriateness of the questions, whether the items were easily understood or the proper extent), to understand the sensitivity of some included questions on it, and for suggestions for improvement. 
Since questionnaire was built from scratch, this research stage seemed to be even more relevant as it would be the only opportunity to conduct a test prior to its experimental application and was intended to be as appropriate as possible.

As a result of the review by the validation committee, it was necessary to divide the general and specific skills and provide a brief description of each in order to reduce misinterpretation by respondents. Finally, the questionnaire was pilot tested on four final-year students and four accounting lecturers with very similar profiles to those who should participate in this study. The questionnaire was then considered perfectly understandable and usable. Regarding ethical issues, it should be noted that before any research was conducted a request for approval of research ethics was made at the institutions involved and a full approval in research ethics was granted for the study.

\section{Sample}

This study is defined within the scope of accounting degrees taught in Portugal, taking into consideration 28 HEIs, which include public and private universities and polytechnics (Table 3), where undergraduate courses in accounting were accredited by the Evaluation and Accreditation Agency for Higher Education at the end of 2013, with students enrolled in the 2013/2014 school year.

Table 2. HEI included in the study

\begin{tabular}{|r|c|c|c|c|}
\hline & \multicolumn{2}{|c|}{ Universities } & \multicolumn{2}{c|}{ Polytechnics } \\
\hline & Public & Private & Public & Private \\
\hline Number of HEIs & 1 & 7 & 13 & 7 \\
\hline Number of courses & 3 & 5 & 24 & 9 \\
\hline
\end{tabular}

The sample includes students enrolled in degrees where accounting is clearly the main axis of professional training - Accounting and Finance, Accounting, Accounting and Administration, Accounting and Financial Management, and Accounting and Taxation - within the scientific area of Group 344 of the National Classification of Education and Training Areas in Portugal, which includes a total of 41 degrees. After data analysis, students enrolled in distance learning courses were excluded due to the specific characteristics of these degrees.

Subsequently, questionnaires were sent directly via a link available at the email address specifically created to send them. Responses were received anonymously and entered directly into a database without an indication of their origin.

The sample size of final-year students was calculated by considering the total number of students enrolled in the last year of the undergraduate accounting courses included in the study: $n=2,608$ individuals. The sample should be $n=335$ final-year students. In total, 357 questionnaires were collected, of which 345 were considered valid.

As for accounting lecturers, we chose to consider those who taught subjects in the major areas of accounting, financial reporting and management accounting in the 2012/2013 school year (the latest available information). The lecturer's population was collected through the Higher Education Faculty Biographical Record, updated December 31, 2013. The sample size of lecturers was calculated based on $n$ $=249$ individuals. Therefore, the sample must have a size of $n=151$ accounting lecturers. In total, 174 questionnaires were collected, 155 of which were considered valid. In this process, we excluded questionnaires with omissions and the same response level for all questions. Although this option has the disadvantage of reducing the number of valid responses, the data analyzed is genuine, avoiding ambiguities and errors in statistical analysis (Hill \& Hill, 2012). 


\section{Data Analysis}

After data collection, descriptive statistics and exploratory data analysis techniques were used to determine the distribution of the data on the possible value scale. For the purpose of this study, general skills were analyzed by factor analysis using the principal component method, which is a multivariate exploratory analysis technique that transforms a set of correlated variables into a smaller set of independent variables, combinations the original variables called original components (Marôco, 2014). The second step was to verify the internal consistency of the data, so that the Cronbach's alpha reliability test was performed. The Kaiser-Meyer-Olkin Index (KMO) and Bartlett's sphericity test confirmed that factor analysis would likely yield satisfactory results.

The last phase of this study consisted of interpreting the results in order to understand if the objectives were achieved and to draw relevant conclusions.

\section{Analysis and Discussion of Results}

This section begins by characterizing respondents and then analyzes the information obtained from questionnaires conducted with final-year students and accounting lecturers based on each of the general skills questions proposed in this instrument.

\section{Characterization and Profile of Respondents}

Table 4 (final-year students) and Table 5 (accounting lecturers) below present the first five demographic and independent questions, allowing the identification of the surveyed population from a statistical and demographic point of view. The characterization of the final-year students who answered the questionnaires considered the following aspects: gender, age range, graduation, educational subsystem and type of HEI attended.

Table 3. Characterization and profile of final-year students $(n=345)$

\begin{tabular}{clc}
\hline Gender & Frequency & Percentage \\
\hline Female & 236 & 68.40 \\
Male & 109 & 31.60 \\
Age range & 235 & 68.10 \\
Below 25 & 55 & 15.90 \\
$26-35$ & 44 & 12.80 \\
$36-45$ & 8 & 2.30 \\
46-55 & 3 & 0.90 \\
Over 55 & & \\
Accounting and Administration & 194 & 56.20 \\
Accounting and Taxation & 60 & 17.40 \\
Accounting & 52 & 15.10 \\
Accounting and Finance & 36 & 10.40 \\
Accounting and Financial Management & 3 & 0.90 \\
Educational subsystem & 333 & 96.50 \\
Polytechnic & 12 & 3.50 \\
University & & \\
Type of HEI attended & 342 & 99.10 \\
Public & 3 & 0.90 \\
Private & &
\end{tabular}


Table 4 indicates that more than half of the students were female $(68.4 \%)$ and most were under 25 years old (68.1\%). The dominant undergraduate course attended was Accounting and Administration (56.2\%), and most respondents $(96.50 \%)$ were enrolled in public polytechnic institutes.

The characterization of the accounting lecturers who participated in the research included: gender, age range, length of service, academic qualifications and current professional situation.

Table 4. Characterization and profile of accounting lecturers $(n=155)$

\begin{tabular}{|c|c|c|}
\hline & Frequency & Percentage \\
\hline \multicolumn{3}{|l|}{ Gender } \\
\hline Female & 83 & 53.50 \\
\hline Male & 72 & 46.50 \\
\hline \multicolumn{3}{|l|}{ Age range } \\
\hline $26-35$ & 15 & 9.70 \\
\hline $36-45$ & 75 & 48.40 \\
\hline $46-55$ & 45 & 29.00 \\
\hline Over 55 & 20 & 12.90 \\
\hline \multicolumn{3}{|l|}{ Length of service } \\
\hline Less than 5 years & 20 & 12.90 \\
\hline 5-9 years & 25 & 16.10 \\
\hline $10-15$ years & 39 & 25.20 \\
\hline 16-19 years & 35 & 22.60 \\
\hline $20-25$ years & 18 & 11.60 \\
\hline More than 25 year & 18 & 11.60 \\
\hline \multirow{2}{*}{\multicolumn{3}{|c|}{$\begin{array}{c}\text { Academic qualifications } \\
\text { Master's }\end{array}$}} \\
\hline & & \\
\hline $\mathrm{PhD}$ & 49 & 31.60 \\
\hline 38. Undergraduate & 19 & 12.30 \\
\hline \multicolumn{3}{|c|}{ Current professional situation } \\
\hline Fully dedicated & 78 & 50.30 \\
\hline Part-time & 44 & 28.40 \\
\hline Full-time & 33 & 21.30 \\
\hline
\end{tabular}

Looking at Table 5, we can see that more than half the accounting lecturers were female (53.5\%). Most were between 36 and 45 years old (48.4\%) and taught from 10 to 15 years old (25.2\%). Regarding academic qualifications, we can see that respondents had a master's degrees $(56.1 \%)$ and more than half of respondents were fully dedicated to lectures $(50.3 \%)$.

\section{Factor Analysis Results}

Exploratory factor analyzes were performed to obtain the most developed skills from the perspectives of final-year students and accounting lecturers. Results are shown in Tables 6 and 7 for final-year students and Tables 8 and 9 for accounting lecturers.

Four factors were identified for final-year students and accounting lecturers. These results explained $69.97 \%$ and $79.11 \%$ of the total variance and 0.929 and 0.946 of the KMO adequacy values for accounting students and lecturers, respectively. For this study, we chose the total variance explained, which is a method that includes enough components to explain $70 \%$ to $90 \%$ of the total variance of the original variants (Jolliffe, 2002). The method proposed by the author involves the collection of factors that explain $70 \%$ to $80 \%$ of the total variation to summarize information contained in the original variables without losing its explanatory power. 
Bartlett's sphericity test was performed for final-year students, who presented a value $\mathrm{P}=0.000(<0.05)$, thus rejecting $\mathrm{H} 0$, concluding that there are significant correlations between the original variables. We can conclude that application of component analysis is valid. The variables are correlated among them, and it is possible to find factors that explain the existing correlations (Marôco, 2014, p. 55). For accounting lecturers, Bartlett's sphericity test has a value of $\mathrm{P}<0.000$, thus rejecting $\mathrm{H} 0$, concluding that the variables are significantly correlated.

We use a factor analysis for the sixteen skills to analyze what are the general skills that final-year students enrolled in undergraduate accounting courses perceive as being developed in their degrees (RQ1). The varimax method was selected for rotation and all attributes with factor loadings greater than 0.5 were retained for the purpose of this analysis.

Table 6 below shows the strategic variables of each major component (size or strategic factor). These variables are placed in descending order of weight. Subsequently, Cronbach's alpha test was performed to verify the consistency of the four main components. It can be concluded that the main component 2 presents a very good correlation between items, and the main components 1, 3, and 4 present a good correlation (Pestana \& Gageiro, 2014, p. 526).

Table 5. Skill development load factor for final-year students

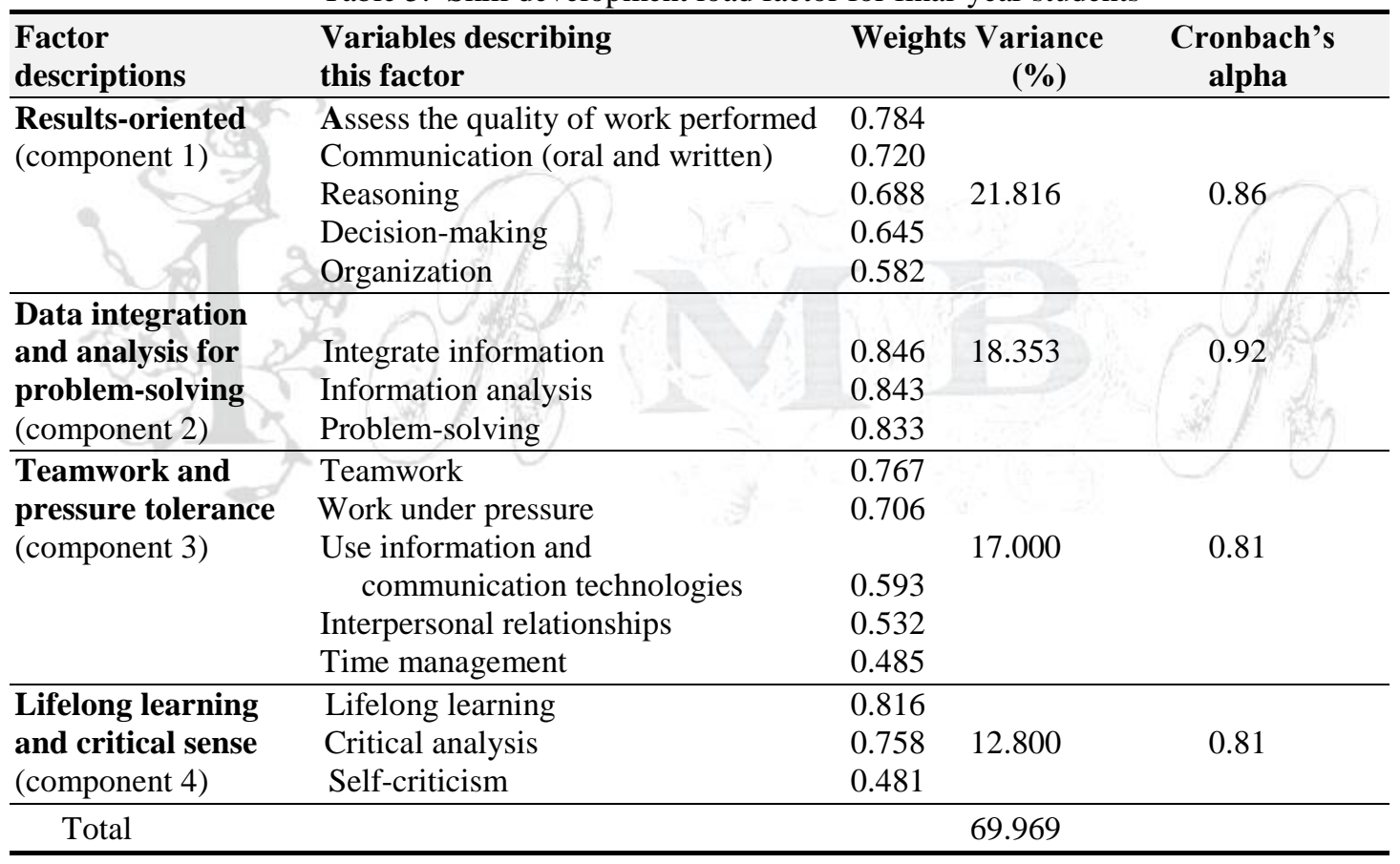

The interpretation of the four factors obtained in Table 6 was performed by analyzing the semantic content of the items, aiming to associate each factor with the previously defined skills. The first factor is composed of items that show how important it is for final-year students to focus on achieving the goals of the assignment and ensuring that the desired results are achieved. The factor was called 'Results-oriented'.

The items in the second factor describe the ability to analyze a given problem and reach reasonable conclusions using a set of data from various sources. This factor may be called 'Data integration and analysis for problem-solving'.

The third factor has been defined as 'Teamwork and pressure tolerance', because the items reflect the ability to integrate work teams both inside and outside their usual context, share information and 
knowledge, contribute to a good working environment, and deal with pressure situations and setbacks in an adequate and professional manner.

Finally, the fourth factor is defined as 'Lifelong learning and critical sense', where the included variables represent the ability to continuously build and seek new knowledge to better meet the demands of each task performed, to grow professionally, to know how to make judgments, to analyze your own actions, and to employ self-correction.

Thus, skills can be grouped into four factors that represent the key dimensions that should be considered when analyzing the final-year students' perceptions.

Table 7 below records the results of the dimensions in terms of mean and standard deviations of the responses obtained from the final-year students in relation to general skills.

Table 6. Mean and standard deviation of final-year students statements

\begin{tabular}{ccc}
\hline Factors & Mean & St. Deviation \\
\hline Results-oriented & $\mathbf{5 . 2 2}$ & $\mathbf{0 . 8 8}$ \\
Assess the quality of work performed & 5.06 & 1.12 \\
Communication (oral and written) & 5.30 & 1.10 \\
Reasoning & 4.93 & 1.25 \\
Decision-making & 5.39 & 0.97 \\
Organization & 5.40 & 1.03 \\
\hline Data integration and analysis for problem-solving & $\mathbf{5 . 2 2}$ & $\mathbf{0 . 8 5}$ \\
Integrate information & 5.21 & 0.93 \\
Information analysis & 5.22 & 0.90 \\
Problem-solving & 5.22 & 0.90 \\
\hline Teamwork and pressure tolerance & $\mathbf{5 . 4 4}$ & $\mathbf{0 . 8 5}$ \\
Teamwork & 5.64 & 1.03 \\
Work under pressure & 5.41 & 1.18 \\
Use information and & & \\
communication technologies & 5.17 & 1.29 \\
Interpersonal relationships & 5.53 & 1.12 \\
Time management & 5.44 & 1.02 \\
\hline Lifelong learning & $\mathbf{5 . 1 0}$ & $\mathbf{0 . 9 2}$ \\
Critical analysis & 5.04 & 1.15 \\
Self-criticism & 5.09 & 1.00 \\
\hline Lifelong & 5.18 & 1.09 \\
\hline
\end{tabular}

The observation of the mean of skills in each dimension (Table 7) shows that final-year students admit that 'teamwork' is the most developed competence $\left(\mathrm{x}_{\mathrm{m}}=5.64\right)$, followed by 'interpersonal relationships' $\left(x_{m}=5.53\right)$. On the other hand, they realize 'reasoning' $\left(x_{m}=4.93\right)$ is less developed in their attended courses. As Table 7 indicates, the dimension that most contributed to skill development was 'Teamwork and pressure tolerance'. Thus, final-year students realize that the course has enabled them to develop the ability to integrate with work teams, share information and knowledge, contribute to a good work environment and deal with pressure situations in an appropriate and professional way.

It can also be seen from Table 7 that the highest mean and lowest standard deviation correspond to 'Teamwork and pressure tolerance'. This result can be explained by the diversity of perceptions expressed in this factor or the need for students to improve their competence in the new technological world (Cory \& Pruske, 2012). 
The first research question (RQ1) focused on the general skills developed by final-year students enrolled in undergraduate accounting courses. Results from factor analysis indicate that they are grouped into four dimensions: 'Teamwork and pressure tolerance', 'Results-oriented', 'Data integration and analysis for problem-solving', and 'Lifelong learning and critical sense'.

Table 8 presents the four dimensions of general skills and their interpretation for accounting lecturers. The variables are placed in descending order of weight. Subsequently, Cronbach's alpha test was performed to verify the consistency of the four main components. It can be concluded that the alpha values for major component 1 should be considered very good and reasonable for components 2, 3 and 4 (Pestana \& Gageiro, p. 526).

Table 7. Skill development load factor for accounting lecturers

\begin{tabular}{|c|c|c|c|c|}
\hline $\begin{array}{l}\text { Factor } \\
\text { descriptions }\end{array}$ & $\begin{array}{l}\text { Variables describing } \\
\text { this factor }\end{array}$ & Weights & $\begin{array}{c}\text { Variance } \\
(\%)\end{array}$ & $\begin{array}{c}\text { Cronbach's } \\
\text { alpha }\end{array}$ \\
\hline Critical sense, lifelong & Critical analysis & 0.82 & & \\
\hline learning and & Self-criticism & 0.81 & & \\
\hline results-oriented & Lifelong learning & 0.79 & & \\
\hline (component 1) & Decision-making & 0.75 & & \\
\hline & Reasoning & 0.72 & 35.502 & 0.96 \\
\hline & Communication (oral and written) & 0.72 & & \\
\hline & Interpersonal relationships & 0.65 & & \\
\hline & Organization & 0.65 & & \\
\hline & Assess the quality of work & & & \\
\hline & performed & 0.61 & & \\
\hline & Time management & 0.54 & & \\
\hline Pressure tolerance and & Work under pressure & 0.76 & 18.288 & 0.77 \\
\hline Teamwork & Teamwork & 0.63 & & \\
\hline (component 2) & & & & \\
\hline Information & Use information and & C & & \\
\hline technologies & communication technologies & 0.89 & 13.590 & 0.76 \\
\hline (component 3) & Integrate information & 0.69 & & \\
\hline Problem-solving & Problem-solving & 0.81 & & \\
\hline (component 4) & Information analysis & 0.50 & 11.728 & 0.79 \\
\hline Total & & & & \\
\hline
\end{tabular}

Table 8 shows that the first factor consists of items that imply the ability to question and analyze the data needed in a rational and intelligent manner to perform tasks, showing interest in expanding knowledge and professional experience to better meet the demands. The ability to make decisions in any situation, to implement solutions efficiently, to communicate them assertively, and to interact appropriately with people with different characteristics are relevant characteristics. This factor is labeled 'Critical sense, lifelong learning, and results-oriented'.

The second factor is called 'Pressure tolerance and teamwork' because it consists of a set of variables related to the ability to properly handle stressful situations and setbacks, to keep emotional control and professional thinking under control, to exhibit behaviors that demonstrate the ease of interacting with the group and collaborating and participating to improve overall group performance.

Factor three 'Information technologies' refers to the ability to properly use information technologies in professional practice as a communication and learning tool and to access and manage information. Finally, the ability to analyze the problems presented and develop reasonable conclusions for their solution using the available information correlates with dimension four, 'Problem-solving'. 
Skills can be grouped into four factors that represent the main dimensions that should be considered when analyzing accounting lecturers' perceptions. Table 9 records the results of the dimensions in terms of mean and standard deviation of the responses obtained from accounting lecturers for general skills.

Table 8. Mean and standard deviation of accounting lecturers statements

\begin{tabular}{lll}
\hline Factors & Mean & St. Deviation \\
\hline Critical sense, lifelong learning and results-oriented & $\mathbf{5 . 5 3}$ & $\mathbf{1 . 1 0}$ \\
Critical analysis & 5.77 & 1.18 \\
Self-criticism & 5.46 & 1.36 \\
Lifelong learning & 5.26 & 1.29 \\
Decision-making & 5.69 & 1.02 \\
Reasoning & 5.45 & 1.28 \\
Communication (oral and written) & 5.61 & 1.09 \\
Interpersonal relationships & 5.74 & 0.96 \\
Organization & 5.77 & 1.09 \\
Assess the quality of work performed & 5.31 & 1.27 \\
Time management & 5.84 & 0.94 \\
\hline Pressure tolerance and teamwork & $\mathbf{5 . 8 2}$ & $\mathbf{0 . 9 1}$ \\
Work under pressure & 5.69 & 1.11 \\
Teamwork & 5.95 & 0.90 \\
\hline Information technologies & $\mathbf{5 . 8 3}$ & $\mathbf{0 . 8 8}$ \\
Use information and communication & & \\
technologies & 5.81 & 0.89 \\
Integrate information & 5.84 & 1.05 \\
\hline Problem-solving & $\mathbf{6 . 1 4}$ & $\mathbf{0 . 8 8}$ \\
Problem-solving & 6.24 & 0.73 \\
Information analysis & 6.05 & 0.98 \\
\hline
\end{tabular}

Looking at Table 9, it can be concluded that accounting lecturers see that 'problem-solving' is the most developed competence $\left(\mathrm{x}_{\mathrm{m}}=6.24\right)$, followed by 'information analysis' $\left(\mathrm{x}_{\mathrm{m}}=6.05\right)$. On the other hand, they realize that 'lifelong learning' $\left(\mathrm{x}_{\mathrm{m}}=5.26\right)$ is less developed by students.

As Table 9 indicates, the dimension that most contributed to skill development was 'Problem-solving'. Thus, it is found that accounting lecturers realize that students develop the ability to analyze problems and develop reasonable conclusions to solve the difficulties presented using the available information, considering the various alternatives and proposing solutions in a timely manner.

It can also be seen from Table 9 that the highest standard deviation corresponds to 'Critical sense, lifelong learning and results-oriented'. This result may be explained by the diversity of perceptions expressed in this factor or the need for accounting lecturers to complement other learning strategies that develop greater selfcriticism in students.

The second research question (RQ2) focused on the general skills that accounting lecturers perceive that final-year students develop during the undergraduate courses they teach. The results obtained by the factor analysis indicate that they are grouped in four dimensions: 'Critical sense, lifelong ability and resultsoriented', 'Pressure tolerance and teamwork', 'Information technologies', and 'Problem-solving'.

Two-factor analyzes revealed several differences in the perceptions of final-year students and accounting lecturers regarding general skill development. In Tables 6 and 8, the factors constructed in the profiles of each group were not the same. As noted above, the results of our factor analysis for final-year students 
revealed that the main influential factor was 'Results-oriented'. Our study also reports that 'Data integration and analysis for problem-solving' is ranked as the second most important factor for final-year students. On the other hand, accounting lecturers considered 'Critical sense, lifelong ability and resultsoriented' as the most important factor.

Earlier studies of the important skills inherent in the accounting profession have found that the labour market considers 'teamwork' indispensable for accounting graduates to succeed (Kavanagh \& Drennan, 2008; Paisey \& Paisey, 2010; Pan \& Perera, 2012). Implementing new teaching methodologies helps develop this competency, such as business simulation practices that stimulate a skill set in students who meet the goals of competency-based higher education, creating active and participatory learning, as reported by Almeida et al. (2015), Burdon and Munro (2017), and Pincus et al. (2017).

Unlike students, accounting lecturers feel that 'problem-solving' skills are one of the most developed ones throughout the course. Although this competence is present in the IES 3 as one of the intellectual skills required by the accounting professional, students do not consider that they are able to solve problems, analyze causal relationships, and set priorities for action.

On the other hand, the contrasting result obtained from accounting students and lecturers may be related to the fact that the student does not see the usefulness of certain content in terms of its later practical application (Arquero \& Fernández-Polvillo, 2019). These authors argue that the link between content and practical utility should be reinforced, especially in terms of theoretical content and some non-technical skills (communication, complex and unstructured problem-solving, application of professional judgment) to which students do not attribute much importance because it does not match your view of typical accounting tasks, although these skills are essential from a professional and higher education perspective.

Therefore, educators should consider adjusting current learning strategies to current reality in order to improve student interest and performance. Perhaps the fact that there are more routine tasks naturally develops less thinking ability when compared to daily calls to solve problems of a different nature.

\section{Conclusions}

The literature shows important and crucial changes in higher education, driven by the rapid advancement of technology and a constantly changing organizational environment. The aim of this paper was to analyze the perceptions of final-year students and accounting lecturers about the development of general skills in firstcycle courses, in order to improve the skills taught in accounting courses to facilitate students' entry into the labour market. The results of our empirical study indicate that there are differences between these two groups in perceived skills.

This research found evidence that final-year students perceive skill development differently from their teachers. Through factor analysis, we found that an important factor, 'teamwork and pressure tolerance', explains the relationships between the variables that measure competency development, the ability to work in teams, the ability to form interpersonal relationships, and the ability to work together. 'Time management' is the most outstanding general skills.

The results for accounting lecturers show that they perceive 'problem-solving', 'information analysis' and 'teamwork' as the most developed skills by final-year students.

These findings seem to be consistent with other studies (Kavanagh \& Drennan, 2008; Paisey \& Paisey, 2010; Pan \& Perera, 2012) that consider the importance of 'teamwork' for the labour market. This skill is considered imperative for accounting graduates to succeed; therefore, it is essential in the context of higher education accounting degrees. 
However, Jackling and De Lange (2009) note that accounting graduates indicated that general skills were not being adequately taught to the degree they attended, and 'teamwork' was one of the divergent skills. The results obtained in this study indicate the exact opposite, perhaps due to the implementation of new teaching methodologies, such as business simulation practices, which stimulate in the student a set of skills that meet the objectives of competence-based higher education, promoting active learning, as reported by Almeida et al. (2015) and Burdon and Munro (2017). Moreover, these results are in line with previous studies, such as Van der Klink et al. (2007). According to these authors, a student in the first cycle of study should develop, among others, the ability to solve problems.

The practical implications derived from our findings may lead accounting educators to find solutions to provide students with cognitive and transversal skills for successful incorporation into the labour market. In this sense, the teaching methodology, combined with different multimedia features such as data mining (Chamizo-Gonzalez et al., 2015), or teaching accounting subjects in Spanish or English as a means of instruction (Rivero-Menéndez et al., 2018), can facilitate the teaching and learning process and improve student motivation.

In this context, only investing in an integrated education system that can promote the holistic development of final-year students will provide adequate support in the process of transition to social and professional life, allowing individuals to make their own choices and respond in the best way possible to the stimuli introduced by the labour market itself. In the future, HEIs need to continue working on new ways of teaching to prepare undergraduate students for rapidly developing work.

Any effort to change the accounting image will probably take several years to become entrenched. The accounting profession must make every effort to promote its image change. In our opinion, in the short and medium term, more research needs to be focused on how accounting educators can encourage change in today's students in the areas of communication and thinking development to facilitate the implementation and success of appropriate pedagogy.

\section{Study Limitations and Future Research Proposal}

Notwithstanding the contributions mentioned, this study is not without its limitations. The first limitation is the great difficulty in getting contacts and responses from final-year students and accounting lecturers, despite the multiple approaches taken. In addition, the results were obtained mainly from polytechnic students and did not include many university responses. Consequently, this would be a fruitful area for future research in order to obtain more generalizable results. For future research, it is important to broaden the scope of this study by focusing on the views of leading firms that recruit accounting graduates in order to confirm or refute the results of this preliminary research.

Given the competitive advantages conferred on prospective graduates in the field of general skills upon entering the labour market, another suggestion would be to try to understand in more detail why some skills are not being properly developed during training.

\section{References}

Almeida, R. (2004). Implementação do Processo de Bolonha a nível nacional. Grupos por área de conhecimento - contabilidade. Parecer MCTES. Lisbon, Portugal: MCTES. Available from http://www.fap.pt/fotos/gca/Bolonha_Contabilidade.pdf. [Consult. 20 fev. 2017].

Almeida, R., Morgado, J., Silva, J., Domingos, R., Santos, A., Marques, A., ... Nogueira, R. (2015). O Projeto em Simulação Empresarial como método de ensino sucesso: A perspetiva dos alunos de contabilidade do ISCAL. Atas do $V$ Congresso dos TOC. Retrieved from https://www.occ.pt/news/trabalhoscongv/pdf/ 49.pdf. 
Arquero, J. L., \& Fernández-Polvillo, C. (2019). Estereotipos contables. Motivaciones y percepciones sobre la contabilidad de los estudiantes universitarios de Administración de Empresas y Finanzas y Contabilidad. Revista de Contabilidad - Spanish Accounting Review, 22(1), 88-99.

Arquero, J. L., \& Tejero, C. (2011). How well adapted are accounting students for Bologna? A comparative analysis of learning styles of Spanish social sciences students. The Spanish Journal of Accounting, Finance and Management Education, 2, 145-156.

Arquero, J. L., Donoso, J. A., Hassall, T., \& Joyce, J. (2001). Vocational skills in the accounting professional profile: The CIMA employers' opinion. Accounting Education: An International Journal, 10(3), 299-313.

Arquero, J. L., Fernández-Polvillo, C., Hassall, T., \& Joyce, J. (2017). Relationships between communication apprehension, ambiguity, tolerance and learning styles in accounting students. Revista de Contabilidad - Spanish Accounting Review, 20(1), 13-24.

Bui, B., \& Porter, B. (2010). The expectation-performance gap in accounting education: An exploratory study. Accounting Education, 19(1-2), 23-50. doi:10.1080/096392809028 75556.

Burdon, W., \& Munro, K. (2017). Simulation: Is it all worth it? The impact of simulation from the perspective of accounting students. The International Journal of Management Education, 15, 429448. doi:10.1016/j.ijme.2017.07.001.

Ceitil, M. (2016). Gestão e desenvolvimento de competências (2nd ed.). Lisbon, Portugal: Edições Sílabo.

Chamizo-Gonzalez, J., Cano-Montero, E., Urquia-Grande, E., \& Muñoz-Colomina, C. (2015). Educational data mining for improving learning outcomes in teaching accounting within higher education. The International Journal of Information and Learning Technology, 32(5), 272-285. doi:10.1108/IJILT08-2015-0020.

Cory, S., \& Pruske, K. (2012). Necessary skills for accounting graduates: An exploratory study to determine what the profession wants. ASBBS Annual Conference: Las Vegas, 19(1), 208-218.

Glynn, S. M., \& Koballa, T. R. Jr. (2006). Motivation to learn college science. In J. J. Mintzes \& W. H. Leonard (Eds.), Handbook of college science teaching (pp. 25-32). Arlington, VA: National Science Teachers Association Press.

Harandi, S. R. (2015). Effects of e-learning on students' motivation. Procedia-Social and Behavioral Sciences, 181, 423-430. doi:10.1016/j.sbspro.2015.04.905.

Hassall, T., Joyce, J., Montaño, J. L. A., \& Anes, J. A. D. (2005). Priorities for the development of vocational skills in management accountants: a European perspective. Accounting Forum, 29(4), 379394. doi:10.1016/j.accfor.2005.03.002.

Hill, M., \& Hill, A. (2012). Investigação por questionário (2nd ed.). Lisbon, Portugal: Edições Sílabo.

International Federation of Accountants. (2011). Competent and versatile. Retrieved from https://www.ifac.org/publications-resources/competent-and-versatile-how-professional-accountantsbusiness-drive-sustainab.

International Accounting Education Standards Board (2015). Handbook of international education pronouncements 2015 Edition. Available from https://www.ifac.org/system/files/publications/files/IAESB-2015-Handbook_0.pdf.

Jackling, B., \& De Lange, P. (2009). Do accounting graduates' skills meet the expectations of employers? A matter of convergence or divergence. Accounting Education: An International Journal, 18(4-5), 369-385. doi:10.1080/09639280902719341.

Jolliffe, I. T. (2002). Principal component analysis (2nd ed.). Nova Iorque, Brazil: Springer.

Kavanagh, M. H., \& Drennan, L. (2008). What skills and attributes does an accounting graduate need? Evidence from student perceptions and employer expectations. Accounting \& Finance, 48(2), 279300. doi:10.1111/j.1467-629x.2007.00245.x.

Lynch, D. (2008). Confronting challenges: motivational beliefs and learning strategies in difficult college courses. College Student Journal, 42(2), 416-421.

Marôco, J. (2014). Análise estatística com o SPSS Statistics (6th ed.). Lisbon, Portugal: ReportNumber.

McClelland, D. C. (1973). Testing for competence rather than intelligence. American Psychologist Journal, 28(1), 1-14. 
Oxford, R., \& Nyikos, M. (1989). Variables affecting choice of language learning strategies by university students. Modern Language Journal, 73(33), 291-300.

Paisey, C., \& Paisey, N. J. (2010). Developing skills via work placements in accounting: Student and employer views. Accounting Forum, 34, 89-108. doi:10.1016/j.accfor. 2009.06.001.

Pan, P., \& Perera, H. (2012). Market relevance of university accounting programs: Evidence from Australia. Accounting Forum, 36, 91-108. doi:10.1016/j.accfor.2011.11.001.

Pestana, M. H., \& Gageiro, J. N. (2014). Análise de dados para ciências sociais: A complementaridade do SPSS. Lisbon, Portugal: Edições Sílabo.

Pincus, K., Stout, D., Sorensen, J., Stocks, K., \& Lawson, R. (2017). Forces for change in higher education and implications for the accounting academy. Journal of Accounting Education, 40, 1-18. doi:10.1016/j.jaccedu.2017.06.001.

Rivero-Menéndez, M., Urquía-Grande, E., López-Sánchez, P., \& Camacho-Miñano, M. (2018). Motivation and learning strategies in accounting: Are there differences in English as a medium of instruction (EMI) versus non-EMI students? Revista de Contabilidad - Spanish Accounting Review, 21(2), 128139. doi.org/10.1016/j.rcsar.2017.04.002.

Rouco, J., \& Sarmento, M. (2012). Diferentes abordagens sobre o conceito de competência. ProeliumRevista Científica da Academia Militar, Série VII(2), 7-29.

Sarmento, M. (2013). Metodologia científica para a elaboração, escrita e apresentação de teses. Lisbon, Portugal: Universidade Lusíada Editora.

Van der Klink, M., Boon, J., \& Schlusmans, K. (2007). Competências e ensino superior profissional: Presente e futuro. Revista Europeia de Formação Profissional, 40(1), 72-89. 